\title{
Perlindungan Hukum dari Negara Terhadap Masyarakat Fakir Miskin Menurut Konsep Welfare State (Studi Pengentasan Kemiskinan Masyarakat di Kota Palembang)
}

\author{
Muhammad Zainul Arifin, Muhammad Syahri Ramadhan, \\ Happy Warsito, Ardian Nugraha \\ Fakultas Hukum, Universitas Sriwijaya, Palembang, Indonesia \\ zainulakim4@gmail.com
}

\begin{abstract}
The process of implementing the concept of a welfare state by the Indonesian government towards its people is a problem of poverty. The number of needy people in Indonesia is enormous. This is what underlies poverty to be considered a serious problem so that the Indonesian government provides specific regulations related to poverty handling through the issuance of Law no. 13 of 2001 concerning Management of the Poor. In the South Sumatra region, particularly the city of Palembang itself, the problem of poverty is a big task that must be faced by regional officials and other related agencies. The Social Service of South Sumatra Province stated that Palembang City was the city with the highest number of poor people compared to other districts / cities in South Sumatra. This of course requires the right policies in handling it, one of which is through the issuance of the Regional Regulation of South Sumatra Province Number 7 of 2017 concerning poverty reduction in South Sumatra.
\end{abstract}

Keywords: Management of the Poor, Welfare State, Palembang City

\begin{abstract}
Abstrak
Proses implementasi konsep negara kesejahteraan (welfare state) yang dilakukan pemerintah Indonesia terhadap rakyatnya ialah persoalan kemiskinan. Jumlah orang fakir miskin di indonesia terkhusus palembang berjumlah 94.599 orang. Hal inilah yang mendasari pemerintah memberikan regulasi secara khusus terkait penanganan kemiskinan di palembang. Pada tahun 2011 pemerintah membuat regulasi konkrit berupa Undang-Undang No. 13 Tahun 2011 tentang Penanganan Fakir Miskin. Di daerah Sumatera Selatan, khususnya kota Palembang sendiri, masalah kemiskinan menjadi tugas besar yang harus dihadapi pejabat daerah dan dinas terkait lainnya. Dinas Sosial Provinsi Sumatera Selatan menyebutkan Kota Palembang sebagai kota tertinggi jumlah penduduk miskinnya dibanding kabupaten/kota lain di Sumsel. Hasil dari penelitian ini akhirnya menyimpulkan bahwa jaring-
\end{abstract}

FOKUS : Jurnal Kajian Keislaman dan Kemasyarakatan Vol. 5, No. 2, 2020

LPPM Institut Agama Islam Negeri (IAIN) Curup - Bengkulu

p-ISSN 2548-334X, e-ISSN 2548-3358

DOI: $10.29240 /$ jf.v5i2.1967 | p. 269-288 
jaring sosial yang dilakukan oleh pemerintah daerah sudah berupaya berjalan semaksimal mungkin guna pengentasan kemiskinan. Meskipun belum sepenuhnya menyelesaikan masalah namun ada langkah progresif berkurangnya masyarakat miskin di kota Palembamg.

Kata Kunci: Penanganan Fakir Miskin, Negara Kesejahteraan, Kota Palembang

\section{Pendahuluan}

Pada dasarnya tujuan didirikannya suatu negara termasuk Indonesia yaitu untuk menciptakan kemakmuran dan kesejahteraan masyarakat. ${ }^{1}$ Pasal 1 ayat (3) UUD 1945 menyebutkan Negara Indonesia adalah negara hukum (rechstaat). Jadi Indonesia tidak hanya berdasarkan atas kekuasaan belaka (machtsstaat). Hal ini berarti bahwa Republik Indonesia ialah negara hukum yang demokratis berdasarkan Pancasila dan Undang-undang Dasar, menjunjung tinggi hak asasi manusia dan menjamin segala warganegara bersamaan kedudukannya di dalam hukum dan pemerintah, serta wajib menjunjung hukum dan pemerintahan itu dengan tidak ada pengecualiannya. Definisi negara menjamin kesejahteraan rakyat begitu sangat luas, Pemerintah Indonesia harus mampu menjamin kesejahteraan rakyatnya baik dari segi ekonomi, sosial maupun politik. ${ }^{2}$ Demi mewujudkan masyarakat Indonesia yang sejahtera, adil, makmur, dan merata secara materiil dan spirituil berdasarkan Pancasila dan UUD 1945, perlindungan hukum dari negara haruslah berjalan secara optimal.

Konsep negara yang dianut oleh bangsa Indonesia adalah negara kesejahteraan (welfare state). Di dalam UUD 1945, kesejahteraan sosial menjadi judul khusus Bab XIV yang didalamnya memuat pasal 33 tentang sistem perekonomian dan pasal 34 tentang kepedulian negara terhadap kelompok lemah (fakir miskin dan anak telantar) serta sistem jaminan sosial. Ini berarti, kesejahteraan sosial sebenarnya merupakan flatform sistem perekonomian dan sistem sosial di Indonesia. Sehingga, sejatinya Indonesia adalah negara yang menganut faham Negara Kesejahteraan (welfare state) dengan model Negara Kesejahteraan Partisipatif (participatory welfare state). Model ini menekankan bahwa negara harus tetap ambil bagian dalam

1 M. Syahri R. Simangunsong, 2018, Realita Hukum Pertanahan Indonesia : Dilematis Kepentingan Hak Privat dan Publik, Komojoyo Press, Yogyakarta, hlm. 24.

${ }^{2}$ Ibid. 
penanganan masalah sosial dan penyelenggaraan jaminan sosial (sosial security), meskipun dalam operasionalisasinya tetap melibatkan masyarakat. Kedua pasal tersebut merupakan suatu hubungan kausalitas yang menjadi dasar disahkannya UUD 1945 oleh para pendiri negara, karena baik buruknya Perekonomian Nasional akan ikut menentukan tinggi rendahnya kesejahteraan sosial.

UUD 1945 tidak hanya dianggap sebagai konstitusi politik, tetapi juga kostitusi ekonomi dan sosial budaya karena itulah konsep negara yang dianut dalam UUD 1945 adalah negara kesejahteraan, namun berbagai masalah pendidikan, kesehatan, pendidikan rasa aman dan kesejahteraan umum belum terselesaikan dengan baik, artinya cita-cita nasional seperti yang dituangkan dalam pembukaan Undang-Undang Dasar 1945, dan implementasi dari Pasal 34 Undang-Undang Dasar 1945 belum berhasil dicapai dengan baik. ${ }^{3}$

Di daerah Sumatera Selatan, khususnya kota Palembang sendiri, masalah kemiskinan menjadi tugas besar yang harus dihadapi pejabat daerah dan dinas terkait lainnya. Dinas Sosial Provinsi Sumatera Selatan menyebutkan Kota Palembang sebagai kota tertinggi jumlah penduduk miskinnya dibanding kabupaten/kota lain di Sumsel. Jumlah penduduk miskin di Palembang dapat mencapai 5.440 KK (Kepala Keluarga) lebih dibandingkan Ogan Ilir yang lebih sedikit jumlah masyarakat miskinnya yang berjumlah sebesar 30.137 KK (Kepala Keluarga). ${ }^{4}$ Hal inilah melandasi Pemerintah Provinsi Sumatera Selatan menerbitkan Peraturan Daerah Provinsi Sumatera Selatan Nomor 7 tahun 2017 tentang penanggulangan kemiskinan di Sumatera Selatan guna untuk merespon tingginya jumlah penduduk miskin yang ada di provinsi Sumatera Selatan terutama di kota Palembang.

Tabel 1. Data Penerima PKH Kota Palembang dan Ogan Ilir

\begin{tabular}{|r|l|l|l|l|}
\hline No & Kecamatan & $\begin{array}{l}\text { Jumlah } \\
\text { Penerima } \\
\text { PKH }\end{array}$ & Kecamatan & $\begin{array}{l}\text { Jumlah } \\
\text { Penerima } \\
\text { PKH }\end{array}$ \\
\hline 1. & Alang-Alang Lebar & 1392 & Indralaya & 2.227 \\
\hline
\end{tabular}

${ }^{3}$ Emir Soendoro, 2009, Jaminan Sosial Solusi Bangsa Indonesia Brdikari, Dinov Progress Indonesia, Jakarta, hlm. 35

Palembang Tertinggi Jumlah Penduduk Miskin melalui http://www.rmolsumsel.com/read/2017/08/15/76990/Palembang-Tertinggi-Jumlah-

Penduduk-Miskin- edisi Selasa, 15 Agustus 2017 diakses pada Minggu, 12 Agustus 2018. 
272 | FOKUS : Jurnal Kajian Keislaman dan Kemasyarakatan Vol. 5, No. 2, 2020

\begin{tabular}{|r|l|l|l|l|}
\hline 2. & Bukit Kecil & 1321 & Indralaya Selatan & 1.184 \\
\hline 3. & Gandus & 3762 & Indralaya Utara & 925 \\
\hline 4. & Ilir Barat I & 3094 & Kandis & 1.25 \\
\hline 5. & Ilir Barat II & 2894 & Lubuk Keliat & 1.645 \\
\hline 6. & Ilir Timur I & 1805 & Muara Kuang & 1.309 \\
\hline 7. & Ilir Timur II & 3615 & Payaraman & 1.197 \\
\hline 8. & Kalidoni & 2907 & Pemulutan & 4.800 \\
\hline 9. & Kemuning & 2165 & Pemulutan Barat & 1.676 \\
\hline 10. & Kertapati & 6547 & $\begin{array}{l}\text { Pemulutan } \\
\text { Selatan }\end{array}$ & 2.132 \\
\hline 11. & Plaju & 4090 & Rambang Kuang & 2.816 \\
\hline 12. & Sako & 1921 & Rantau Alai & 828 \\
\hline 13 & Seberang Ulu I & 9660 & Rantau Panjang & 740 \\
\hline 14 & Seberang Ulu II & 4584 & Sungai Pinang & 1.291 \\
\hline 15. & Sematang Borang & 1195 & Tanjung Batu & 2.451 \\
\hline 16. & Sukarami & 3490 & Tanjung Raja & 1.310 \\
\hline & Total & $\mathbf{5 4 4 4 2}$ & Total & $\mathbf{3 0 . 1 7 0}$ \\
\hline
\end{tabular}

(Data ini dikutip dari Badan Pusat Statistik Kota Palembang dan Ogan Ilir, Sumatera Selatan $)^{5}$

Dari uraian tabel 1 dapat dilihat bahwa jarak masyarakat miskin dan butuh bantuan di kota palembang hampir 2 kali lipat dari kabupaten terdekat dengan kota palembang. Persentase penduduk miskin di daerah perkotaan pada Maret 2019 sebesar 12,19 persen turun menjadi 11,94 persen pada September 2019 dan naik menjadi 12,16 persen pada Maret 2020. Sementara persentase penduduk miskin di daerah perdesaan turun dari 13,02 persen pada Maret 2019 menjadi 12,93 persen pada September 2019 dan naik menjadi 12,96 persen pada Maret 2020. ${ }^{6}$

${ }^{5}$ Data dikutip dari Badan Pusat Statistik Sumatera Selatan dan dapat diakses melalui Link https://oganilirkab.bps.go.id/pressrelease/2020/07/15/275/persentase-penduduk-miskinmaret-2020-naik-menjadi-12-66-persen.html diakses pada tanggal 6 Desember 2020

${ }^{6}$ Badan Pusat Statistik, Ibid 
Adanya Peraturan Daerah Provinsi Sumatera Selatan Nomor 7 tahun 2017 tentang penanggulangan kemiskinan di Sumatera Selatan ini juga tidak serta merta menjadi solusi mutlak dalam melakukan pengentasan masyarakat fakir miskin di Kota palembang. Manifestasi dari nilai - nilai konsep negara kesejahteraan (welfare state) belum tertananm secara komprehensif baik dalam regulasi maupun realisasi kebijakan terkait penanganan masyarakat fakir miskin.

Atas dasar masalah di atas maka penulis akan membuat kajian yang berjudul Bagaimana Perkembangan Implementasi Konsep Negara Kesejahteraan Terhadap Kemiskinan di Kota Palembang ?

Lokasi penelitian ini adalah di kota Palembang, dalam penelitian ini digunakan pendekatan penelitian deskriptif analitis. Sejalan dengan latar belakang dan tujuan dalam penelitian yang bersifat eksploratoris sebagai landasan utama dan tolak ukur dalam penyusunan maka dilakukan penelitian lapangan selain itu juga digunakan penelitian kepustakaan dengan cara pengumpulan data-data dan teori yang ada melalui kepustakaan, sehingga penelitian ini merupakan penelitian hukum bersifat eksploiratoris yang bermaksud menguji suatu hipotesa.

Adapun dalam mencari, data dan informasi serta mengumpulkannya, peneliti menggunakan tiga teknik pencarian data, yaitu: a) Observasi; Pengamatan dilakukan secara intensif terhadap pola pengentasan kemiskinan yang dilakukan oleh dinas sosial dan lembaga terkait. Hal ini dilakukan untuk mengetahui seberapa efektif langkah yang dilakukan guna pengentasan kemiskinan ini; b) Wawancara (Interview). Peneliti melakukan wawancara mengunakan teknik wawancara tak tersetuktur. Teknik ini peneliti pilih karena lebih bersifat luwes atau lentur dan dirancang agar sesuai dengan subjek dan suasana pada wawancara berlangsung; c) Dokumentasi

Adapun dalam analisis data, peneliti mendiskripsikan dan menguraikan tentang bagaimana langkah-langkah konkrit yang dilakukan oleh pemerintah terkait pengentasan kemiskinan dan solusi konkritnya. Setelah data terkumpul, maka data tersebut dianalisis untuk mendapatkan konklusi. Hal iti dilakukan dengan menggunakan beberapa metode, yaitu: 1) Reduksi data; data yang berkaitan dengan jumlah masyarakat miskin dan implementasi UndangUndang Nomor 13 tahun 2011 tentang pengentasan kemiskinan dikumpulkan kemudian dipetakan untuk dipilah dan dipilih mana data yang dibutuhkan dan 
mana data yang tidak dibutuhkan. Data yang dibutuhkan akan dilanjutkan untuk dianalisis dan data yang tidak dibutuhkan akan dibuang atau dikesampingkan; 2) Penyajian data; penyajian data ini sebagai salah satu bagian dari teknik menganalisis data yang bertujuan untuk memudahkan peneliti dalam memahami apa yang terjadi sebagai dasar untuk membuat rencana berikutnya; 3) Conclusion Drawing; Langkah terakhir dalam analisi data sebuah penelitian adalah penarikan kesimpulan. Kesimpulan yang dikemukan di awal masih bersifat sementara. Kesimpulan itu akan berubah bila tidak ditemukan bukti yang kuat untuk mendukungnya atau ditemukan bukti yang justru malah berbeda dengan apa yang sudah disimpulkan.

Peneliti juga melakukan pengecekan data sehingga data penelitian menjadi lebih valid, pengecekan itu dilakukan dengan perpanjangan kehadiran peneliti, ketekunan pengamatan (keabsahan data yang memanfaatkan sesuatu yang lain diluar data untuk keperluan pengecekan atau sebagai perbandingan terhadap data

\section{Hasil Dan Pembahasan}

\section{Tinjauan Umum tentang Fakir Miskin}

Kemiskinan adalah suatu situasi di mana seseorang atau rumah tangga mengalami kesulitan untuk memenuhi kebutuhan dasar, sementara lingkungan pendukungnya kurang memberikan peluang untuk meningkatkan kesejahteraan secara berkesinambungan atau untuk keluar dari kerentanan. ${ }^{7}$ Kemiskinan dipahami sebagai keadaan kekurangan uang dan barang untuk menjamin kelangsungan hidup. Dalam arti luas, mengatakan bahwa kemiskinan adalah suatu intergrated concept yang memiliki lima dimensi, yaitu kemiskinan (proper), ketidakberdayaan (powerless), kerentanan menghadapi situasi darurat (state of emergency), ketergantungan (dependence), dan keterasingan (isolation) baik secara geografis maupun sosiologis. ${ }^{8}$

Asumsi yang kuat bahwa negara Kesatuan Republik Indonesia didesain sebagai Negara Kesejahteraan (welfare state) dapat dilacak dari bunyi

\footnotetext{
${ }^{7}$ A. Cahyat, Gönner, C, and M Haug, 2007, Mengkaji Kemiskinan dan Kesejahteraan Rumah Tangga :

Sebuah Panduan dengan Contoh dari Kutai Barat Indonesia, CIFOR Indonesia, Bogor, hlm. 2.

${ }^{8}$ Adit Agus Prastyo, 2010, Analisis Faktor-Faktor yang Mempengaruhi Tingkat Kemiskinan, UNDIPPRESS, Semarang, hlm. 18.
} 
pembukaan UUD 1945 bahwa "Pemerintah melindungi segenap bangsa dan seluruh tumpah darah, memajukan kesejahteraan umum dan mencerdaskan kehidupan bangsa". Selain itu beberapa pasal dalam UUD 1945 mencerminkan pula nilai dasar dari Negara Kesejahteraan (welfare state), seperti:pasal 27 (2) Tiap-tiap warga negara berhak atas pekerjaan dan penghidupan yang layak bagi kemanusiaan; Pasal 28A Setiap orang berhak untuk hidup serta berhak mempertahankan hidup dan kehidupannya; demikian pula pada pasal 28B, 28C, 28H, 31, 33, dan pasal 34 .

Menurut Pasal 1 angka 1 UU No. 13 Tahun 2011 tentang Penanganan Fakir Miskin menyebutkan fakir miskin adalah orang yang sama sekali tidak mempunyai sumber mata pencaharian dan/atau mempunyai sumber mata pencaharian tetapi tidak mempunyai kemampuan memenuhi kebutuhan dasar yang layak bagi kehidupan dirinya dan/atau keluarganya.

Hak warga Negara dibedakan antara hak konstitusional dan hak legal. Hak konstitusional adalah hak-hak yang dijamin dalam Undang - Undang Dasar Negara Republik Indonesia Tahun 1945 yang merupakan hukum dasar tertinggi dalam penyelenggaraan kehidupan berbangsa dan bernegara, ${ }^{9}$ sedangkan hak legal timbul berdasarkan peraturan perundang - undangan. Sebagai seseorang yang memiliki hak dasar, terdapat tuntutan perlindungan sehingga menciptakan konstitusi yang melindungi kepentingan individu dan pembatasan kesuasaan Negara

Secara umum kemiskinan dapat ditinjau dari dua sisi yaitu ${ }^{10}$ :

1. Kemiskinan absolut, Kemiskinan diukur dengan membandingkan tingkat pendapatan orang dengan tingkat pendapatan yang dibutuhkan untuk memperoleh kebutuhan dasarnya yakni makanan, pakaian dan perumahan agar dapat menjamin kelangsungan hidupnya. Bank dunia mendefinisikan kemiskinan absolut sebagai hidup dengan pendapatan di bawah USD \$1/hari dan kemiskinan menengah untuk pendapatan di bawah $\$ 2 /$ hari.

2. Kemiskinan relatif, Kemiskinan dilihat dari aspek ketimpangan sosial di mana seseorang dapat memenuhi kebutuhan dasar minimumnya tetapi masih jauh lebih rendah dibanding masyarakat sekitarnya (lingkungannya). Semakin besar ketimpangan antara tingkat penghidupan Hal.9.

${ }^{9}$ Utrecht, 1962, Pengantar Hukum Administrasi Negara Indonesia, Ichtiar, Jakarta,

${ }^{10}$ A. Cahyat, Gönner, C, and M Haug, op.cit, hlm. 26. 
golongan atas dan golongan bawah maka akan semakin besar pula jumlah penduduk yang dapat dikategorikan miskin. Dengan kata lain, kemiskinan relatif berkaitan erat dengan permasalahan distribusi pendapatan.

Kemiskinan yang terjadi di Indonesia secara sosiologis memiliki beberapa pola, yaitu ${ }^{11}$ :

1. Kemiskinan Individu terjadi karena adanya kekurangan-kekurangan yang dipandang oleh seseorang mengenai syarat-syarat yang diperlukan untuk mengatasi dirinya dari lembah kemiskinan.

2. Kemiskinan relatif merupakan pengertian yang disebut dengan social economics status atau disingkat dengan SES (biasanya untuk keluarga atau rumah tangga). Dalam hal ini diadakan perbandingan antara kekayaan materil dari keluarga atau rukun tetangga di dalam suatu komunitas teritorial

3. Kemiskinan Strukturalmerupakankemiskinan yang disebabkan oleh struktur sosial ekonomi yang sedemikian rupa sehingga masyarakat menjadi bagiannya. Kemiskinan struktural dipahami sebagai kemiskinan yang terjadi disebabkan oleh ketidakmerataan sumberdaya karena struktur dan peran seseorang dalam masyarakat.

4. Kemiskinan Budayaadalah kemiskinan yang diderita oleh suatu masyarakat di tengah-tengah lingkungan alam yang mengandung banyak bahan mentah yang bisa dimanfaatkan untuk memperbaiki taraf hidup.

Banyak faktor penyebab terjadinya kemiskinan, kemiskinan apabila ditinjau dari segi ekonomi maka akan terdiri dari ${ }^{12}$ :

1. Kemiskinan secara makro lahir karena adanya ketidaksamaan pola kepemilikan sumber daya, adanya sekelompok orang yang memonopoli kepemilikan atas sumber daya dapat mengakibatkan munculnya kemiskinan.

2. Kemiskinan muncul sebagai akibat perbedaan dalam kualitas sumberdaya manusia, hal ini terlihat bahwa kekurangan orang miskinuntuk maju adalah karena mereka tidak memiliki keilmuan, pengetahuan dan keahlian seperti yang dimiliki oleh orang yang kaya.

3. Kemiskinan muncul sebagai akibat perbedaan akses dalam modal, halini

\footnotetext{
${ }^{11}$ Parsudi suparlan, 1985, Kemiskinan di Perkotaan, Sinar Harapan, Jakarta, hlm. 18.

12 Mudrajad Kuncoro, 1997, Masalah, Kebijakan, dan Politik Ekonomika Pembangunan, Erlangga, Jakarta, hlm.80.
} 
yang sering kali menjadi ketakutan orang apabila hendakberwirausaha yaitu keterbatasan modal, sementara di sisi lain adasekelompok orang yang mampu memiliki akses terhadap sumbersumber permodalan yang ada.

Kemiskinan di Indonesia harus benar-benar ditangani secara komprehensif oleh Pemerintah Indonesia. Pasal 1 angka 2 UU No. 13 Tahun 2011 tentang Penanganan Fakir Miskin menyebutkan Penanganan fakir miskin adalah upaya yang terarah,terpadu, dan berkelanjutan yang dilakukan Pemerintah, pemerintah daerah, dan/ataumasyarakat dalam bentuk kebijakan, program dan kegiatan pemberdayaan, pendampingan, sertafasilitasi untuk memenuhi kebutuhan dasar setiapwarga negara. Adapun maksud kebutuhan dasar ini sebagaiman diatur dalam Pasal 1 angka 3 UU No. 13 Tahun 2011 tentang Penanganan Fakir Miskin yang menyebutkan kebutuhan dasar adalah kebutuhan pangan,sandang, perumahan, kesehatan, pendidikan, pekerjaan, dan/atau pelayanan sosial.

Kemiskinan adalah suatu situasi di mana seseorang atau rumah tangga mengalami kesulitan untuk memenuhi kebutuhan dasar, sementara lingkungan pendukungnya kurang memberikan peluang untuk meningkatkan kesejahteraan secara berkesinambungan atau untuk keluar dari kerentanan. ${ }^{13}$ Kemiskinan dipahami sebagai keadaan kekurangan uang dan barang untuk menjamin kelangsungan hidup. Dalam arti luas, mengatakan bahwa kemiskinan adalah suatu intergrated concept yang memiliki lima dimensi, yaitu kemiskinan (proper), ketidakberdayaan (powerless), kerentanan menghadapi situasi darurat (state of emergency), ketergantungan (dependence), dan keterasingan (isolation) baik secara geografis maupun sosiologis. ${ }^{14}$

Menurut Pasal 1 angka 1 UU No. 13 Tahun 2011 tentang Penanganan Fakir Miskin menyebutkan fakir miskin adalah orang yang sama sekali tidak mempunyai sumber mata pencaharian dan/atau mempunyai sumber mata pencaharian tetapi tidak mempunyai kemampuan memenuhi kebutuhan dasar

13 A. Cahyat, Gönner, C, and M Haug, 2007, Mengkaji Kemiskinan dan Kesejahteraan Rumah Tangga : Bogor, hlm. 2.

Sebuah Panduan dengan Contoh dari Kutai Barat Indonesia, CIFOR Indonesia,

${ }^{14}$ Adit Agus Prastyo, 2010, Analisis Faktor-Faktor yang Mempengaruhi Tingkat Kemiskinan, UNDIPPRESS, Semarang, hlm. 18. 
yang layak bagi kehidupan dirinya dan/atau keluarganya.

Tingkat kemiskinan Kota Palembang sebagai ibukota Provinsi Sumatera Selatan masih cukup tinggi dibandingkan dengan kabupaten/kota lain di Provinsi Sumatera Selatan. Berdasarkan data BPS (2018), jumlah penduduk miskin penerima Bantuan Langsung Tunai (BLT) di Kota Palembang sebanyak 99.396 KK atau 17,86\%dari seluruh penerima BLT di Provinsi Sumatera Selatan atau kabupaten/kota tertinggi penerima BLT. Tanpa mengabaikan fakta bahwa Kota Palembang sebagai kota dengan jumlah penduduk terbesar di Sumatera Selatan, angka tersebut perlu mendapatkan perhatian. Jumlah penduduk miskin tersebut paling banyak tersebar di 10 kelurahan, yaitu : 3 - 4 Ulu, Sentosa, Sei Lais, Talang Betutu, Karya Baru, Sukajadi, Sri Mulya, Pulokerto, Karya Jaya, dan Kramasan. Sedangkan jumlah kelurahan yang ada di Kota Palembang sebanyak 36 kelurahan dengan jumlah kecamatan sebanyak 15 kecamatan. ${ }^{15}$

Implementasi kebijakan dapat dilakukan melalui pendekatan top-down dan pendekatan bottom-up. Dalam pendekatan top-down, implementasi kebijakan dilakukan secara tersentralisasi dan dimulai dari aktor pemerintah tingkat atas serta keputusan penetapan kebijakan publik oleh pemerintah tingkat atas. Pelaku kebijakan dalam pencapaian tujuan dan sasaran dari kebijakan tersebut sesuai prosedur dan tujuan yang telah digariskan oleh pembuat kebijakan dari emerintah tingkat atas. Dalam pendekatan bottom-up, dimana pelaksanaan kebijakan yang terformulasi dari inisiasi warga masyarakat setempat. Hal ini berkaitan bahwa, masalah yang terjadi pada level tingkat bawah dan masyarakat secara substansial hanya diketahui,dimengerti dandipahami secara baik oleh warga masyarakat itu sendiri. Argumentasi yang disampaikan bahwa masalah dan persoalan yang terjadi pada level daerah dan desa hanya dapat dimengerti dan dipahami secara baik dan benar oleh warga masyarakat setempat. ${ }^{16}$

Implementasi kebijakan melalui Program Keluarga Harapan,

\footnotetext{
${ }^{15}$ Bank Indonesia,"Mengempeskan” Kantong Kemiskinan Kota Palembang Melalui Pengembangan Budidaya Itik Di Kelurahan Pulokerto", https://www.bi.go.id/id/publikasi/kajianekonomiregional/sumsel/Documents/e77c64b410ac4 51faba2de1924a028e8Suplemen6.pdf, dikutippadatanggal 12 September 2020

${ }^{16}$ Kiagus Muhammad Faisal1, Jumroh, Implementasi Kebijakan Pemberdayaan masyarakat miskin (Studi tentang Program Keluarga Harapan Di Kota Palembang), Jurnal Ilmu Administrasi dan Studi Kebijakan (JIASK), hlmn 1
} 
dilaksanakan di Kota Palembang tahun 2018. Program ini bertujuan untuk mempercepat terwujudnya kemandirian masyarakat melalui peningkatan kapasitas masyarakat, pemerintah lokal, serta penyediaan prasarana dan sarana sosial dasar dan ekonomi. Selama ini, implementasi kebijakan pemberdayaan masyarakat miskin, melalui proses implementasi Program Keluarga Harapan belum efektif dalam upaya meningkatkan kesejahteraan masyarakat danmengurangi kemiskinan.

Hal ini disebabkan, belum dilibatkannya secara langsung masyarakat miskin dalam proses pengambilan keputusan bersama perumusan dan penetapan program. Dalam pelaksanaan politik desentralisasi dan otonomi daerah, masyarakat merupakan pilar utama pembangunan dan pemberdayaan, karena pemberdayaan masyarakat merupakan hak rakyat. Disamping itu, belum efektifnya hubungan antara pemerintah dengan pemerintah daerah dalam proses pelaksanaan kegiatan program, karena terbatasnya peran pemerintah daerah. Hubungan yang dibangun dalam proses implementasi kebijakan pemberdayaan masyarakat miskin, sejalan dengan pelaksanaan politik desentralisasi dan otonomi daerah yang harmonis, koordinasi yang serasi dan sinergi antara pemerintah, pemerintah daerah, "stakeholders" dan masyarakat miskin.

Ada berbagai hal yang menjadi faktor penyebab kemiskinan di di Kota Palembang. Tiga faktor utama berikut adalah beberapa di antaranya.

\section{Tingkat Pendidikan yang Masih Rendah}

Salah satu faktor utama yang melatarbelakangi masalah kemiskinan di Palembang adalah masih rendahnya tingkat pendidikan. Masyarakat yang tinggal di pelosok daerah, misalnya, memiliki akses terbatas untuk menjangkau fasilitas pendidikan lanjutan, terutama perguruan tinggi. Sebagai dampaknya, mereka tidak mendapatkan pendidikan pengetahuan dan keterampilan yang dibutuhkan untuk mengusahakan pekerjaan.

Meski demikian, masyarakat kota palembang yang telah disuguhi akses pendidikan yang lebih mudah pun terkadang masih terkendala biaya pendidikan yang mahal. Itulah mengapa alternatif pendidikan dan pelatihan keterampilan harus disediakan agar dapat mempersiapkan individu untuk mengusahakan kehidupannya,

2. Ketidakpedulian terhadap Keadaan Sosial di Sekitar 
Faktor lain yang menyebabkan kemiskinan adalah kurangnya kepedulian sesama terhadap keadaan sosial sebagian masyarakat yang masih jauh dari kategori berkecukupan, apalagi sejahtera. Akan tetapi, faktor ini juga bisa menjadi dua sisi pisau yang berlainan jika tidak dipertimbangkan secara bijak.

Di satu sisi, memberikan bantuan dana kepada masyarakat miskin adalah suatu hal yang dapat membantu mereka memenuhi kebutuhan. Namun, di sisi lain, hal ini dapat menciptakan mental ketergantungan (dependency). Oleh karena itu, solusi terbaik tidak hanya dilakukan dengan memberi, tetapi juga memberdayakan.

\section{Lapangan Kerja yang Kurang Memadai}

Faktor penyebab kemiskinan lainnya adalah tidak tersedia lapangan kerja yang memadai, terutama bagi sumber daya manusia yang tidak memiliki cukup keterampilan. Hal ini juga ada kaitannya dengan pola pikir masyarakat yang masih beranggapan bahwa lapangan kerja hanya sebatas kesempatan yang diberikan oleh negara maupun perusahaan swasta.

Pada kenyataannya, lapangan kerja bisa didapatkan di mana saja atau bahkan, dikembangkan sendiri. Tidak sedikit contoh masyarakat yang membuka usaha dengan modal minim, tetapi dapat menghasilkan keuntungan yang menjanjikan.

Itulah sejumlah faktor utama yang menjadi penyebab kemiskinan di kota Palembang. Sebagai bagian dari masyarakat yang tinggal di negeri ini, kita sebenarnya bisa turut membantu mengurangi tingkat kemiskinan di Palembang. Salah satu usaha yang bisa dilakukan adalah berpartisipasi dalam sejumlah program crowdlending atau penanaman modal bagi pengembangan usaha kecil.

\section{Peran Pemerintah Dalam Memberikan Kesejahteraan}

Secara teoritis garis kemiskinan dapat dihitung dengan menggunakan tiga pendekatan, yaitu: pendekatan produksi, pendapatan dan pengeluaran. Garis kemiskinan yang ditentukan berdasarkan tingkat produksi, misalnya: produksi padi per kapita hanya dapat menggambarkan kegiatan produksi tanpa memperhatikan pemenuhan kebutuhan hidup. Perhitungan garis kemiskinan dengan pendekatan pendapatan rumah tangga dinilai paling baik. Cara ini tidak mudah dilakukan karena kesulitan untuk memperoleh data pendapatan 
rumahtangga secara akurat. Untuk mengatasi kesulitan dalam pengumpulan data pendapatan, maka garis kemiskinan ditentukan dengan pendekatan pengeluaran yang digunakan sebagai proksi atau perkiraan dari pendapatan rumah tangga. Garis kemiskinan yang dipergunakan BPS dinyatakan sebagai jumlah rupiah yang dikeluarkan atau dibelanjakan untuk memenuhi kebutuhan konsumsi yang setara dengan 2100 kalori per kapita ditambah dengan pemenuhan kebutuhan pokok minimum lainnya seperti sandang, perumahan, kesehatan, pendidikan, angkutan dan bahan bakar.

Langkah-langkah kebijakan penanggulangan kemiskinan dilakukan baik oleh Pemerintah Pusat maupun oleh Pemerintah daerah terdiri dari 3 (tiga) program yakni :

a. Bidang Kesehatan ${ }^{17}$

Nama Program Indonesia Sehat, Penyelenggara Badan Penyelenggara Jaminan Sosial, Media Kartu Indonesia Sehat, Cakupan Hingga Satuan Tingkat Desa (POSYANDU), Penerimaan Masyarakat kurang Mampu yang telah memiliki BPJS PBI ditambahkan kelompok Penyandang Masalah Kesejahteraan Sosial (PMKS) serta bayi baru lahir.

b. Bidang Pendidikan ${ }^{18}$

Nama Program Indonesia Pintar, Media Kartu Indonesia Pintar Penerimaan Semua Anak SD/MI, SMP/MTs, SMA/MA, SMK/MAK, yang berasal dari keluarga pemegang KKS/KPS, PKH, Panti Asuhan dan Anak Yatim Piatu. Masyarakat kurang Mampu yang telah memiliki BPJS PBI ditambahkan kelompok Penyandang Masalah Kesejahteraan Sosial (PMKS) serta bayi baru lahir, Bentuk Penyalura Simpanan Tabungan di Kantor POS atau Bank yang ditunjuk bisa dicairkan atau tetap disimpan.

c. Bidang Sosial Ekonomi

Nama Program Kesejahteraan Sosial, Media Kartu Kesejahteraan Sosial (KKS), Penerimaan keluarga kurang mampu di seluruh Indonesia, mencakup juga penghuni panti asuhan, panti jompo, dan panti sosial lainnya, Besaran Rp. 200.000,-/Keluarga/Bulan. Bentuk Penyaluran Simpanan/

17 Nina Herlina, dan Mamay Komariah, Peran Pemerintah Dalam Pengentasan Kemiskinan Di Kabupaten Ciamis, Jurnal Ilmiah Galuh Justisi, Hlm 3

${ }^{18}$ Nina Herlina, dan Mamay Komariah, Ibid 
Tabungan di Kantor POS atau Bank yang ditunjuk bisa dicairkan atau tetap disimpan

Sejak persoalan kemiskinan dan ketimpangan sosial mulai memasuki sejarah umat manusia, tidak sedikit upaya yang dilakukan untuk mengatasinya. Banyak cara dan upaya telah dilakukan. Masdar telah mengidentifikasikan bahwa secara umum ada tiga pendekatan kemiskinan. Pertama adalah Pendekatan Pasivisme- - Religious. Pendekatan ini didasarkan pada pendapat bahwa segala sesuatunya telah ditentukan langsung oleh Tuhan Yang Maha Kuasa, sehingga ada atau tidaknya kemiskinan dan ketimpangan social bukanlah urusan manusia. Kedua, yaitu Pendekatan SekularismeKapitalisme. Pendekatan ini didasarkan pada pendapat bahwa kemiskinan merupakan persoalan manusia yang sama dengan persoalan hidup lainnya. ${ }^{19}$

Pasa dasarnya manusia bisa mengatasinya dengan kekuatan sendiri. Namun, ada padanyaan apakah memang kemiskinan itu perlu diatasi ? Hal ini bertolak dari pendirian bahwa segala sesuatu memiliki kegunaan (fungsi) sendiri bagi tertibnya kehidupan. Dengan demikian kemiskinan harus tetap ada. Membiarkan kemiskinan yang keterlaluan memang tidak bijaksana, akan tetapi melenyapkan kemiskinan juga berbahaya. Oleh sebab itu, kemiskinan tersebut tidak mutlak harus dihilangkan tapi yang penting mengendalikan-nya agar tidak merusak tatanan kehidupan. Ketiga Pendekatan MaterialismeKomunisme. Pendekatan ini sebagai antitesis terhadap pendekatan pertama dan kedua. Pendlrian dasar dari pendekatan ini adalah kemiskinan bisa diatasi dan harus diatasi oleh orang-orang miskin itu sendiri.

Negara merupakan organisasi tertinggi di antara satu kelompok ata beberapa kelompok masyarakat yang mempunyai cita-cita untuk bersatu hidup di dalam daerah tertentu, dan mempunyai pemerintahan yang berdaulat. ${ }^{20}$ Kesejahteraan merupakan kesejahteraan masyarakat dan perorangan. Kesejahteraan masyarakat adalah kesejahteraan semua perorangan secara keseluruhan anggota masyarakat. Dalam hal ini kesejahteraan yang dimaksudkan adalah kesejahteraan masyarakat. Dan kesejahteraan perorangan adalah kesejahteraan yang menyangkut kejiwaan (state of mind). Perorangan

\footnotetext{
${ }^{19}$ Valeriana Darwis dan A Rozany Nurmanaf, Pengentasan Kemiskinan : Upaya Yang Telah Dilakukan Dan Rencana Waktu Mendatang, ejournal.ipdn.ac.id, dikutip tanggal 19 September 2020

${ }^{20}$ Moh Mahfud MD, 2013, Dasar dan Struktur Ketatanegaraan Indonesia (Edisi Revisi), Jakarta, Renaka Cipta, hlm. 64
} 
yang diakibatkan oleh pendapatan kemakmuran dan faktor - faktor ekonomi lainnya.

Dari Negara bagian barat seperti di Negara Inggris, konsep welfare state dipahami sebagai alternatif terhadap the poor law yang kerap menimbulkan stigma, karena hanya ditujukan untuk member bantuan bagi orang-orang miskin. Berbeda dengan sistem dalam the poor law, Negara kesejahteraan difokuskan pada penyelenggaraan system perlindungan social yang melembaga bagi setiap orang sebagai cerminan dari adanya hak kewarganegaraan (right of citizenship), di satu pihak, dan kewajiban Negara (state obligation), di pihak lain. Negara kesejahteraan ditujukan orang tua dan anak-anak, pria dan wanita, kaya dan miskin, sebaik dan sedapat mungkin. Ia berupaya untuk mengintegrasikan sistem sumber dan menyelenggarakan jaringan pelayanan yang dapat memelihara dan meningkatkan kesejahteraan (well-being) warga Negara secara adil dan berkelanjutan. ${ }^{21}$

Tipe negara hukum ini sering juga disebut sebagai negara hukum dalam arti yang luas atau disebut pula sebagai negara hukum modern. Negara dalam pengertian ini bukan saja menjaga keamanan saja tetapi secara aktif turut serta dalam dalam urusan kemasyarakatan demi mensejahterakan rakyat. Oleh sebab itu pengertian negara hukum dalam arti luas sangat erat hubungannya dengan pengertian negara kesejahteraan atau (welfare state). ${ }^{22}$ Dalam negara kesejahteraan sekarang ini tugas negara dalam menyelenggarakan kepentigan umum menjadi sangat luas, kemungkinan melanggar kepentingan rakyat oleh perangkat negara menjadi sangat besar. Untuk melaksanakan semua tugas tersebut, maka administrasi negara memerlukan kemerdekaan, yaitu kemerdekaan untuk dapat bertindak atas inisiatif sendiri untuk untuk dapat bertindak atas inisiatif sendiri terutama dalam penyelesaian soal-soal genting yang timbul secara mendadak dan peraturan penyelesainnya belum ada, yang belum dibuat oleh badan badan kenegaraan yang diserahi fungsi legislatif. Dalam hal tersebut administrasi negara, dipaksa untuk bertindak cepat tidak dapat menunggu perintah dari badan-badan kenegaraan yang diserahi fungsi legislatif. ${ }^{23}$

\footnotetext{
${ }^{21}$ Ibid, hlm. 65.

${ }^{22}$ Sjachran Basah, 1977, Simposium Peradilan Tata Usaha Negara, BPHN, binacipta, hlm. 111.

${ }^{23}$ E. Utrech, 1982, Pengantar Hukum Administrasi Negara Indonesia, Yogyakarta, Liberty, hlm. 23
} 
Luasnya fungsi pemerintahan dalam negara hukum modern ini, maka tentu saja makin luas pula peranan hukum administasi didalamnya. Dengan demikian maka dalam tipe negara kesejahteraan sekarang ini peranan hukum administrasi sangat dominan. ${ }^{24}$ Sukar untuk dibayangkan suatu negara modern saat ini tanpa adanya hukum administrasi negara didalamnya. Bahkan sebagaimana ditunjukkan W.Friedmann serta penulis-penulis lainnnya juga di Inggris dan Amerika, konsep negara kesejahteran (welfare state) dan perkembangan sosial telah mendesak perlunya diadakan pemikiran kembali mengenai peradilan administrasi itu. Padahal sebagaimana diketahui bahwa negara-negara tesebut pada mulanya sukar sekali menerima secara terbuka adanya peradilan administrasi.

Negara kesejahteraan bukanlah satu konsep dengan pendekatan baku. Negara kesejahteraan lebih sering ditengarai dari atribut-atribut kebijakan pelayanan dan transfer sosial yang disediakan oleh Negara (pemerintah) kepada warganya, sepertin pelayanan pendidikan, transfer pendapatan, pengurangan kemiskinan, sehingga keduanya (Negara kesejahteraan dan kebijakan sosial) sering diidentikan. ${ }^{25}$ Negara kesejahteraan, pada dasrnya, mengacu pada peran Negara yang aktif dalam mengelola dan mengorganisasi perekonomian yang di dalamanya ,mencakup tanggung jawab Negara untuk menjamin ketersediaan pelayan kesejahteraan dasar dalam tingkat tertentu bagi warganya. Negara kesejahteraan berusaha membebaskan warganya dari ketergantungan pada mekanisme pasar untuk mendapatkan kesejahteraan (dekomodifikasi) dengan menjadikannya sebagai hak setiap warga yang dapat diperoleh melalui perangkat kebijakan sosial yang disediakan oleh Negara. ${ }^{26}$

Setiap negara tentunya mempunyai arah tujuan yang hendak dicapai. Oleh karena itu, berbagai upaya negara untuk mewujudkan harapan tersebut dapat dilakukan dengan mewujudkan kegiatan negara yang berujung terciptanya kesejahteraan dan kemakmuran rakyat. Immanuel Kant menyatakan bahwa tujuan dari negara ialah melindungi dan menjamin ketertiban hukum agar hak dan kemerdekaan warga negara dapat terbina dan

${ }^{24}$ SF Marbun et. al., 2001, Dimensi-Dimensi Pemikiran/ Hukum Admistrasi Negara, UII Press, Yogyakarta, hlm.1.

${ }^{25}$ Siswono Yudo Husodo,2006, Mimpi Negara Kesejahteraan : Peran Negara dalam Produksi dan Alokasi Kesejahteraan Sosial, LP3ES, Jakarta, hlm. 8

${ }^{26}$ Ibid, hlm. 9 
terpelihara. ${ }^{27}$ Dengan merujuk kepada pernyataan Immanuel Kant ini di dalam upaya negara dalam menjamin hak dan kemerdekaan warga negaranya ini dapat direalisasikan jika fungsi-fungsi negara itu dapat berjalan dengan baik. Pada dasarnya fungsi-fungsi negara ini terdiri dari empat fungsi yaitu ${ }^{28}$ :

1. Menyejahterakan serta memakmurkan rakyat. Negara yang sukses dan maju adalah negara yang dapat membuat masyarakat bahagia secara umum dari sisi ekonomi dan sosial kemasyarakatan

2. Melaksanakan ketertiban. Untuk menciptakan suasana dan lingkungan yang kondusif dan damai diperlukan pemeliharaan ketertiban umum yang didukung penuh oleh masyarakat.

3. Pertahanan dan keamanan. Negara harus dapat memberi rasa aman serta menjaga dari segala macam gangguan dan ancaman yang datang dari dalam maupun dari luar.

4. Menegakkan keadilan. Negara membentuk lembaga-lembaga peradilan sebagai tempat warganya meminta keadilan di segala bidang kehidupan.

Melindungi hak-hak setiap warga negara juga merupakan salah satu poin penting dalam dalam upya negara yang mempunyai kewajiban untuk menyejahterakan dan memakmurkan rakyat di Indonesia. Termasuk juga kewajiban negara melindungi hak-hak warga negara untuk memperoleh tempat tinggal dan penghidupan yang layak sebagaimana dijelaskan dalam dalam Pasal 28H ayat (1) UUD 1945 yang menyebutkan Setiap orang berhak untuk hidup sejahtera lahir dan batin, bertempat tinggal, dan mendapatkan lingkungan hidup yang baik dan sehat serta berhak memperoleh pelayanan kesehatan.

\section{Kesimpulan}

Berdasarkan uraian di atas dapat disimpulkan bahwa kebijakan pemerintah terkait strategi pengentasan kemiskinan di Kota Palembang berjalan cukup baik. Namun ada beberapa hal yang masih menjadi pekerjaan rumah yang harus diselesaikan pemerintah palembang yakni :

\footnotetext{
${ }^{27}$ Menurut Immanuel Kant untuk tercapainya suatu tujuan negara maka diperlukan adanya Undang - Undang yang merupakan penjelmaan kehendak umum ( volonte general ), dan karenanya harus ditaati oleh siapa pun, rakyat maupun pemerintah. Dikutip dari Amzulian Rifai. 2010. Teori Sifat Hakikat Negara, Malang : Penerbit Tunggal Mandiri Publishing. hlm. 19

${ }^{28}$ Loc. Cit. Hlm. 14
} 
Pertama. Dalam mengimplementasikan strategi pengentasan kemiskinan dalam konsep negara kesejahteraan, diperlukan kerjasama yang sinergis antara pemerintah pusat dengan pemerintah kabupaten/kota, serta kemitraan sektor publik dan sektor swasta. Untuk itu, pemerintah daerah perlu lebih transparan dan menyediakan informasi yang mudah dijangkau dan terpercaya mengenai iklim bisnis di Kota Palembang.

Kedua. Menciptakan lingkungan pendukung yang stabil untuk pembangunan ekonomi, Menarik investor, Mendukung wirausaha lokal, misalnya melalui keringanan pajak selama tahap awal, Menentukan upah minimum bagi karyawan perusahaan untuk mengatasi jerat utang, Membentuk dan menegakkan peraturan keselamatan kerja dan persyaratan kesehatan dasar bagi karyawan

Ketiga. Penguatan realisasikan 3 (Tiga) program utama yakni, Bidang Kesehatan, Bidang Pendidikan, Bidang Sosial Ekonomi.

Diharapkan dengan penguatan 3 point penting ini pengentasan kemiskinan di Kota Palembang dapat menjadi solusi dan memecahkan masalah sehingga tercipta konsep Walfare State (Konsep Negara Kesejahteraan) berkeadilan di kota Palembang.

\section{Daftar Pustaka}

A. Cahyat, Gönner, C, and M Haug, 2007, Mengkaji Kemiskinan dan Kesejahteraan Rumah Tangga : Sebuah Panduan dengan Contoh dari Kutai Barat Indonesia, CIFOR Indonesia, Bogor

Adit Agus Prastyo, 2010, Analisis Faktor-Faktor yang Mempengaruhi Tingkat Kemiskinan, UNDIPPRESS, Semarang

Emir Soendoro, 2009, Jaminan Sosial Solusi Bangsa Indonesia Brdikari, Dinov Progress Indonesia, Jakarta

Adit Agus Prastyo, 2010, Analisis Faktor-Faktor yang Mempengaruhi Tingkat Kemiskinan, UNDIPPRESS, Semarang

Utrecht, 1962, Pengantar Hukum Administrasi Negara Indonesia, Ichtiar, Jakarta

Parsudi suparlan, 1985, Kemiskinan di Perkotaan, Sinar Harapan, Jakarta 
Mudrajad Kuncoro, 1997, Masalah, Kebijakan, dan Politik Ekonomika Pembangunan, Erlangga, Jakarta.

Kiagus Muhammad Faisal1, Jumroh, Implementasi Kebijakan Pemberdayaan masyarakat miskin (Studi tentang Program Keluarga Harapan Di Kota Palembang), Jurnal Ilmu Administrasi dan Studi Kebijakan (JIASK)

M. Syahri R. Simangunsong, 2018, Realita Hukum Pertanahan Indonesia : Dilematis Kepentingan Hak Privat dan Publik, Komojoyo Press, Yogyakarta.

Valeriana Darwis dan A Rozany Nurmanaf, Pengentasan Kemiskinan : Upaya Yang Telah Dilakukan Dan Rencana Waktu Mendatang, ejournal.ipdn.ac.id, dikutip tanggal 19 September 2020

Moh Mahfud MD, 2013, Dasar dan Struktur Ketatanegaraan Indonesia (Edisi Revisi), Jakarta, Renaka Cipta

Sjachran Basah, 1977, Simposium Peradilan Tata Usaha Negara, BPHN, binacipt

E. Utrech, 1982, Pengantar Hukum Administrasi Negara Indonesia, Yogyakarta, Liberty

SF Marbun et. al., 2001, Dimensi-Dimensi Pemikiran/ Hukum Admistrasi Negara, UII Press, Yogyakarta

Siswono Yudo Husodo,2006, Mimpi Negara Kesejahteraan : Peran Negara dalam Produksi dan Alokasi Kesejahteraan Sosial, LP3ES, Jakarta

Amzulian Rifai. 2010. Teori Sifat Hakikat Negara, Malang : Penerbit Tunggal Mandiri Publishing.

Palembang Tertinggi Jumlah Penduduk Miskin melalui http://www.rmolsumsel.com/read/2017/08/15/76990/Palembang-

Tertinggi-Jumlah-Penduduk-Miskin- edisi Selasa, 15 Agustus 2017 diakses pada Minggu, 12 Agustus 2018.

Muhammad Zainul Arifin, Understanding The Role Of Village Development Agency In Decision Making, Kader Bangsa Law Review,http://ojs.ukb.ac.id/index.php/klbr https://scholar.google.co.id/citations?user=SFDX82UAAAAJ\&hl=id https://unsri.academia.edu/MuhammadZainulArifin 
Bank Indonesia, "Mengempeskan" Kantong Kemiskinan Kota Palembang Melalui Pengembangan Budidaya Itik Di Kelurahan Pulokerto", https://www.bi.go.id/id/publikasi/kajianekonomiregional/sumsel/Doc uments/e77c64b410ac451faba2de1924a028e8Suplemen6.pdf, dikutippadatanggal 12 September 2020

Muhammad Zainul Arifin, Implementasi Peraturan Pemerintah (PP) Nomor 8 Tahun 2016 Tentang Dana Desa Yang Bersumber Dari Anggaran Pendapatan Dan Belanja Negara (Studi Kasus Desa Datar Balam Kabupaten Lahat), Jurnal Fiat Justicia, http://journal.ukb.ac.id/journal/detail/288/implementasi-peraturanpemerintah-pp--nomor-8-tahun-2016-tentang-dana-desa-yangbersumber-dari-anggaran-pendapatan--dan-belanja-negara--studikasus-desa-datar-balam-kabupaten-lahat https://unsri.academia.edu/MuhammadZainulArifin

Muhammad zainul Arifin, Penerapan Prinsip Detournement De Pouvoir Terhadap Tindakan Pejabat Bumn Yang Mengakibatkan Kerugian Negara Menurut Undang-Undang Nomor 17 Tahun 2003 Tentang Keuangan Negara, Jurnal Nurani, http://jurnal.radenfatah.ac.id/index.php/Nurani/article/view/2741/207 $\underline{0}, \underline{\text { https://unsri.academia.edu/MuhammadZainulArifin }}$

Muhammad Zainul Arifin, Korupsi Perizinan Dalam Perjalanan Otonomi Daerah Di Indonesia, Lex Librum : Jurnal Ilmu Hukum, http://www.lexlibrum.id/index.php/lexlibrum/article/view/138/pdf , https://scholar.google.co.id/citations?user=SFDX82UAAAAJ\&hl=id 